\title{
Is 'Good Governance' an Appropriate Model for Governance Reforms? The Relevance of East Asia for Developing Muslim Countries
}

\author{
Mushtaq H. Khan
}

\section{Introduction}

Governance is what states do, and since states play a vital role in the development process, almost all economists can agree that governance must be important for development. The growing recognition within mainstream economics that governance is important is simply a belated recognition within economic orthodoxy that the state plays a critical role even in a market-oriented society. The controversy and debate is about what the feasible governance capabilities are for a poor developing country attempting to develop in a global market with an essentially market-oriented economy. The answer to this is not as obvious as it may seem. The answer provided by the good governance approach is based on a theoretical understanding of a market economy that is contested by many economists supporting the construction of a market-oriented economy. But most significantly, the good governance approach ignores the feasibility of achieving these governance capabilities in poor countries, and therefore overlooks alternative methods of overcoming the obstacles and constraints that are preventing many developing countries from fully participating in and benefiting from the global economy.

Markets are simply mechanisms for private contracting. The good governance reform agenda is based on the presumption that efficient markets are achievable in developing countries, and are sufficient for achieving sustained growth and development. These presumptions are derived from a specific reading of institutional economics that is plausible in theoretical terms even though many of the theoretical links that it asserts can be strongly challenged in terms of alternative readings of orthodox economic theory. The specific claim of good governance theory is while market failures in developing countries can be serious; the best way to address these market failures is by improving the efficiency of the market through good governance reforms. The experience of intervention to correct market failures in most developing countries after they became independent from colonial powers left a lot to be desired. Even though most of these countries did better after independence than they had under colonial rule, many eventually began to run into fiscal and banking sector problems by the 1970s. These problems were often the result of inadequate governance capabilities to manage their interventions properly, resulting for instance in attempts to accelerate industrialization with subsidies for infant industries without adequate performance standards being enforced.

A perception developed within mainstream economics through the 1980 s that while market failures could potentially be important, the cost of government failures when states attempted to correct market failures in these ways was likely to be even greater than the cost of the initial market failure[1-2]. The policy consensus of the 1980s was that the role of government should be reduced, but it eventually became clear that even this was inadequate because market failures remained significant. The good governance reform agenda subsequently emerged to address this problem from a 
different angle. Instead of trying to improve on previous attempts at correcting market failures by strengthening requisite governance capabilities, the good governance agenda argued that governments should instead focus on governance capabilities to make markets work efficiently. Market failure would then be indirectly reduced and so would the need for specific interventions to address these market failures.

The argument that was now developed was that market failure happens primarily because developing countries do not have well-defined property rights, a rule of law to adjudicate conflicts and a state that is restrained from expropriation and rent creation. All of these features of developing country markets raise the 'transaction costs' of trying to agree on and enforce contracts in markets, and this is the ultimate source of the market failure that developing countries suffer from. So if governance reforms could reduce these transaction costs by, for instance, improving the definition of property rights and the rule of law, and reducing corruption and expropriation in the economy, market failures would be significantly reduced and private contracting would then be able to allocate resources efficiently and drive growth and poverty reduction in these countries.

This is why the good governance reform agenda can be described as an agenda for market-enhancing governance[3-4]. It is certainly theoretically plausible. The question is whether it is a practical route to governance reform in developing countries. Can these reforms be implemented to an extent that will significantly increase market efficiency, and will this improvement in market efficiency be sufficient to drive economic growth and broad-based development? One way to answer these questions is to look for any historical evidence of countries that followed good governance reforms and as a result achieved sustained growth and development. Despite the strong correlation between high per capita incomes and market enhancing governance, the evidence is much shakier when we begin to look for countries that first did good governance reforms and then achieved growth and development. The absence of any significant evidence of such a trajectory raises doubts about the practical plausibility of the underlying theory even if it makes sense $a$ priori.

In fact, the weakness of the available evidence leads us to suggest that the theory underpinning good governance theory is not actually plausible because these reforms to achieve market-enhancing governance capabilities in poor countries are difficult to implement in the absence of a significant social surplus and therefore the prior existence of a sufficiently productive economy, for reasons that we will briefly explain later. In contrast, the empirical evidence, such as it is, strongly suggests that in reality developing countries did not follow such a route on their way to prosperity. Instead, they had a variety of other governance capabilities that allowed them to sustain growth by addressing specific market failures, and we describe these capacities as growth-enhancing governance capabilities. The contemporary reform agenda is in real danger of setting vulnerable developing countries unachievable tasks and inadvertently furthering the frustration and despair that often already exists. In many Islamic countries there is already frustration with reform agendas that have created social disruption and pain without leading to any observable improvements in developmental prospects. This has led to disillusionment with many governments, and this can only deepen if unrealistic strategies continue to be followed without any critical interrogation of their empirical and theoretical roots. 


\section{Market-Enhancing versus Growth-Enhancing Governance}

The contemporary consensus about the governance required for development is based on the assumption that efficient markets are achievable to a sufficient extent in poor countries to sustain development without requiring any significant effort to correct market failures. However, achieving efficient markets does require some governance capabilities, and this governance agenda can be described as an agenda of developing market-enhancing governance conditions[5-6]. The common feature of these governance reforms is to make markets more efficient by reducing market transaction costs. In theory, all market failures are ultimately due to transaction costs that prevent potentially beneficial private contracts being executed. And therefore, again in theory, if transaction costs across the board could really be significantly reduced, specific interventions to correct market failures would become unnecessary.

These arguments build on a number of selectively chosen links established by New Institutional Economics and the New Political Economy. The major links are summarized in Figure 1. It is important to note that these are by no means uncontested links even in terms of mainstream institutional theories. Link 1 is the claim that economic stagnation is ultimately due to high transaction cost markets, or in other words, market failures[5]. This link describes a tautology, because all missed opportunities for development can be defined as market failures. However, the tautology directs our attention to a debate between two very different approaches to dealing with market failures. The first and more conventional approach is to identify market failures that are particularly important in specific contexts and to address these with appropriate solutions as well as where necessary, the development of specific governance capabilities for their implementation. The second approach which has implicitly been adopted by the good governance approach is to argue that piecemeal corrections of market failures are unnecessary if generic improvements in market efficiency through good governance reforms can be achieved.

Link 2 shows the innovation of the new good governance agenda, which argues that instead of addressing these market failures individually, governments should try and make markets across the board more efficient by addressing the underlying causes of market failure, such as weak property rights, the weak rule of law and arbitrary interventions [5-8]. The tautological part of the theory is that markets are essentially systems of contracts. If the absence of clear expectations and rights prevent contracting, market failure will follow by definition. But why do high transaction cost markets characterize every developing country? The specific response of good governance theory is not necessarily the only way of thinking about the causes and solutions to market failures. Instead of looking at the full range of possible explanations, in particular the cost of establishing efficient markets even to the extent that they are efficient in advanced countries, Link 3 asserts that unstable property rights, a poor rule of law and expropriation attempts by states are primarily the result of small groups engaging in rent seeking and corruption[2, 9-13].

Finally, the good governance approach has to explain why corruption and rent seeking appear to be widespread in every developing country, particularly given the significant negative effects attributed to them. Once again, the good governance approach identifies a selective set of reasons, not the full range that contemporary theory has identified. In particular, as Link 4 shows, the approach asserts that small corrupt groups can profit from rent seeking and corruption at the expense of the 
majority because government accountability is weak or non-existent $[5,14-15]$. In fact, rent seeking is widespread in all societies, including advanced ones. As Stiglitz and others have pointed out, rents are an essential part of the normal operation of market economies, as well as being the subject of redistributive politics without which societies would not survive politically[16-17]. It follows therefore that rent seeking is an essential element in all societies.

The good governance approach does not ask a number of important questions, in particular why some rent seeking creates rents that are particularly damaging, while other countries appear to have rent seeking that sustains growth-enhancing rents. It also does not ask why poor countries appear to have significantly greater illegal rent seeking which is an important component of corruption, while rich countries appear to be able to legalize and regulate a greater part of rent seeking[18-20]. Link 5 completes the cycle for the good governance approach because economic stagnation in turn prevents the poor from mobilizing and enables autocracy to continue.

On the basis of these theoretical links the good governance agenda argues that it is necessary to complement liberalization and other market reforms with a simultaneous set of governance reforms that include improvements in the rule of law, defining and protecting property rights better, fighting corruption and rent seeking and embedding democracy and decentralization. As we have already argued, the power of the good governance agenda has been that many of these reforms are perceived as desirable by many civil society groups in developing countries as goals that are desirable in themselves. The issue of concern of for us is not whether these goals should be abandoned, but rather whether they are achievable in developing countries to an extent that they can form the basis of a poverty reduction and development agenda.

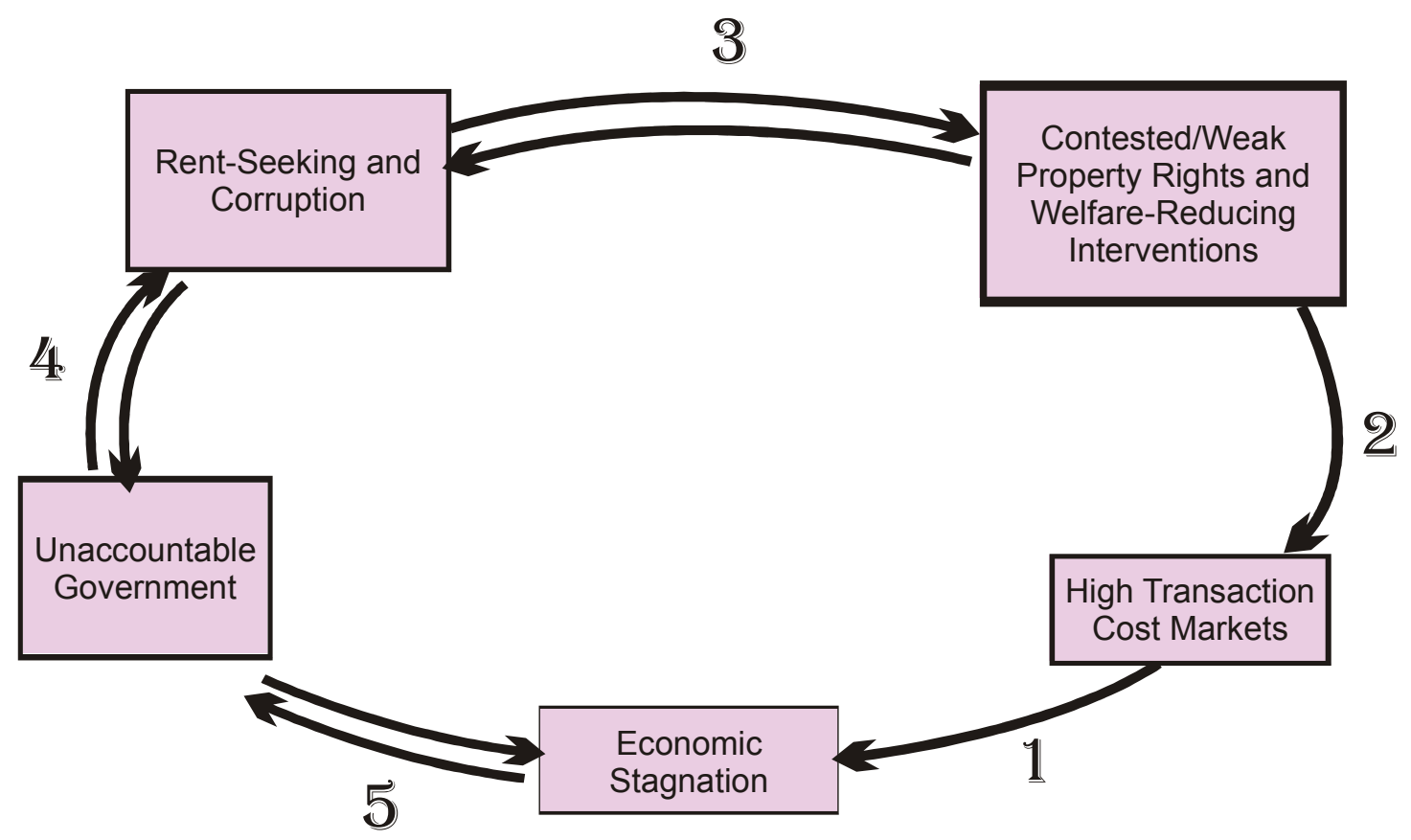

Figure 1 Theoretical Links in the Good Governance Agenda 
The problem for the good governance agenda is that these are not the only theoretical links that can explain the persistence of patron-client politics, autocracy, corruption, weak rule of law and contested property rights in developing countries. We will not review the alternative theoretical arguments explaining these phenomena in poor countries as this has already been done elsewhere[16, 19-22]. The pertinent issue for us now is that even if the theoretical links asserted in the good governance argument are partially relevant, there is little evidence that good governance sets achievable governance goals for poor countries. Indeed, no poor country appears to achieve high scores in these governance capabilities regardless of their economic performance and development strategies.

It is important to reiterate that the importance of markets in fostering and enabling economic development is not in question. Economic development is likely to be more rapid if markets mediating resource allocation (in any country) become more efficient. The development debate is rather about the extent to which markets can be made efficient in developing countries, and whether maximizing the efficiency of markets (to the degree that is achievable) is sufficient to maximize the pace of development. The alternative approach to governance argues not that markets should be supplanted, but rather that they will remain inherently inefficient in developing countries in the foreseeable future due to certain limitations in the structural characteristics of the economy that will always remain until a substantial degree of development is achieved.

Given the possibility that there are structural factors preventing markets achieving significant efficiency, it follows that successful development requires critical governance capacities to address specific market failures. This is a very different reform agenda compared to the good governance one which presumes that effective across-the-board market efficiency can be achieved through this route. In fact, the historical evidence strongly suggests that successful developing countries did not achieve across-the-board market efficiency through good governance reforms, but rather had governance capabilities to correct market failures that were specific to their development strategies and social requirements.

In particular, the evidence of successful East Asian developers of the last five decades and of China over the last three decades shows that the governance capacities that mattered were very different from the good governance capabilities. In terms of the market-enhancing conditions prioritized by the good governance approach, East Asian states and China often performed rather poorly. Democratic accountability was typically low, corruption was high and property rights were typically not well defined[21]. Instead, these states had effective institutions that could accelerate growth in conditions of technological backwardness and high transaction costs. To distinguish these governance capabilities from the good governance ones, we define these developmental governance capabilities as growth-enhancing governance.

Growth is clearly not sufficient for broad based development, but sustaining growth is a necessary part of achieving sustainable development. Without growth broad-based development is arithmetically impossible unless the country is already very rich in per capita terms and the only thing required is redistribution. On the other hand, if broadbased development cannot be achieved in line with growth, a growth strategy can become politically unsustainable. The capacity to correct critical market failures 
constraining development therefore to a large extent requires governance capabilities to sustain growth, and these capacities are a necessary component of developmental capabilities. The broader political and redistributive institutions that sustain growth and ensure that it is broad-based can differ from country to country, but no country has achieved broad-based development without sustaining relatively high growth for long periods of time[23].

Box 1 Market-Enhancing versus Growth-Enhancing Governance Capabilities

The dominant 'good governance' reforms aim to promote governance capabilities that are market-enhancing: they aim to make markets more efficient by reducing transaction costs. To the extent that these reforms can be implemented they are likely to improve market outcomes in developing countries. Transaction costs are the costs of using markets to allocate resources. A fundamental requirement of efficient (low transaction cost) markets is that property rights should be well-defined and wellprotected, and for there to be a good rule of law so that contracts can be easily and cheaply enforced.

The key market-enhancing governance goals are to set up institutions that:

- Protect and Maintain Stable Property Rights

- Enforce a Rule of Law and Effective Contract Enforcement

- Minimize Rent Seeking and Corruption

- Achieve a Transparent and Accountable Provision of Public Goods in line with Democratically Expressed Preferences

However, there are structural and financial constraints that can prevent significant progress in developing these capabilities in poor countries. Given these constraints, growth can require targeted strategies whose implementation requires specific capabilities that we describe as growth-enhancing governance capabilities.

Growth-enhancing governance capabilities are capabilities that allow developing countries to cope with the property right instability of early development, manage technological catching up, and maintain political stability in a context of endemic and structural reliance on patron-client politics.

Key growth-enhancing governance goals are to achieve institutional-governance capabilities to:

- Organize and enable transfers of land and resources to productive sectors in a context where land and asset markets are generally inefficient

- Address labour market failures that result in inadequate training and investment in human capital

- Address failures in capital markets that result in inadequate savings and investment, and inadequate investment in learning and adopting new technologies

- Maintain political stability and acceptable redistributive justice in a context of rapid social transformation 
Box 1 summarizes the main characteristics of governance emphasized in these two contrasting approaches. Market-enhancing governance is about setting up effective institutions that can enforce property rights across the board, enforce a rule of law, limit corruption and rent seeking and achieve political accountability. This is essentially the 'good governance' agenda. In theory, these capabilities would allow the developing country to achieve more rapid growth and development, but we will see that this expectation is unlikely to be borne out because the implementation of these governance goals is virtually impossible to any significant extent in poor countries. If progress on immediately achieving market-enhancing governance is likely to be very limited, growth and development may depend on the achievement of a much more targeted set of governance capabilities that enable the overcoming of specific market failures and constraints that stand in the way of growth. Therefore, what we describe as a growth-enhancing governance agenda would try to identify and set up institutional capabilities that are effective in addressing critical market failures that are relevant for a particular developing country at a particular stage of its development. The range of capabilities here are clearly much broader, and the relevant market failures that need to be addressed and which can feasibly be addressed may be different in different countries.

Depending on the initial conditions, it may only be possible to develop effective growth-enhancing governance capabilities to a much more limited extent in some countries compared to others. But it is also most unlikely that poor countries will be able to enforce property rights and a rule of law effectively enough to achieve low transaction costs and efficient markets (which the market-enhancing governance agenda wants to achieve). In such a context, it is important to have at least some growth-enhancing institutions with the relevant governance capabilities on the part of the state to make these institutions effective. For instance, institutions may be required to assist investors to acquire land and other resources in a context of otherwise high transaction costs. Similarly, it may be vital to address failures in labour markets that prevent labour upskilling, backed by appropriate governance capabilities to ensure that the country achieves and maintains global competitiveness in at least some sectors. The same applies to institutions that address some of the critical capital market failures in developing countries, given that across the board improvements in capital market efficiency can take decades to achieve. If focused financing institutions can provide financing and risk sharing for critical sectors in a context of generally high transaction costs, and provided (growth-enhancing) governance capabilities can be developed to effectively operate these financing institutions, the effects for sustaining growth and development can be significant.

This is why identifying necessary growth-enhancing governance capabilities and selecting the ones that can be feasibly and effectively developed in a particular country may be critical for sustaining growth and development. The growthenhancing institutions that will be most appropriate, and the optimal scale on which they can operate will be different in different countries because of differences in their initial conditions. But clearly, the total absence of such institutions will result in lost growth opportunities in a context where markets are structurally inefficient.

The two sets of governance capabilities are not necessarily mutually exclusive, but the distinction between them is important, particularly if an exclusive focus on achieving market-enhancing governance capabilities diminishes the capacity of states to develop 
growth-enhancing governance capabilities. In particular, if structural economic and political factors prevent the achievement of market-enhancing governance capabilities to a significant extent, a focus on trying to achieve these will be particularly frustrating for poor countries because the effort will not pay off in terms of higher or more sustainable growth and is likely eventually to be abandoned with significant economic and political consequences.

Market failures in land, labour and capital markets that constrain growth in developing countries are, of course, widely acknowledged in economic theory. In the period up to the 1980s the consensus within economics was that states in developing countries needed to intervene to correct these market failures to promote development. Indeed, the interventionist policies of many developing countries in industrial policy, trade policy and so on were often justified in terms of addressing these market failures. However, it was not recognized at the time that the correction of market failures required strong governance capabilities for managing these interventions. These are precisely the capabilities that we have described as growthenhancing governance capabilities. The absence of effective growth-enhancing governance capabilities in many countries trying to overcome market failures in this period led to significant government failures. The short-term benefits of subsidies and interventions were captured by powerful interests who then failed to deliver productivity growth or new investments. Dissatisfaction with the results of intervention led to the counterrevolution within economics in the 1980s and the abandonment of intervention to correct market failures in many developing countries[24].

However, the wholesale abandonment of attempts to correct market failures is increasingly recognized as an over-reaction and a mistake[25]. A more appropriate response would have been to focus on a less ambitious set of corrections for market failures and the development of appropriate governance capabilities for managing these corrections. Instead, the consensus in the 1980s and 1990s abandoned piecemeal corrections to market failures and shifted to a much more ambitious strategy of fixing market failures across the board through market-enhancing (good governance) reforms. Initially, the policy shift was in the direction of the structural adjustment strategies of the 1980s where the aim was primarily to reduce the scope of the state, but by the 1990s the consensus had shifted to the good governance agenda summarized in Figure 1.

Unfortunately, the case study evidence shows that developmental success in poor and emerging countries has always been based on very specific governance capabilities to address critical market failures. A significant part of the asset and resource reallocations necessary for accelerating development in developing countries have taken place through non-market processes or market processes assisted by administrative and political measures precisely because markets remain essentially inefficient at early stages of development regardless of attempts to make them otherwise. Examples of non-market asset transfers that were significant in underpinning growth processes include the creation and support of technology acquisition by the chaebol in South Korea in the 1960s using public resources and the creation of the Chinese TVEs using public resources in the $1980 \mathrm{~s}$ and their privatization in the 1990s. Successful developers have displayed a range of institutional and political capacities that enabled 
semi-market and non-market asset and property right re-allocations that were growth enhancing, thereby indirectly addressing failures in land and capital markets. In contrast, in less successful developers, the absence of necessary governance capabilities meant that non-market transfers descended more frequently into predatory expropriation that impeded development. In these countries, government failures prevented the resolution of critical market failures.

Labour market failures that prevent adequate investment in training and skills acquisition are also well known, and these are also unlikely to be adequately addressed through improvements in good governance. In fact, successful developing countries did not wait to solve their skills and training problems while attempting to achieve good governance. Yet they were able to finance public investments in skill acquisition significantly. But even more importantly, they had the governance capabilities to ensure that these investments would not be wasted through the provision of training of indifferent quality that would fail to raise productivity and global competitiveness. The lesson for developing countries that are trying to improve their developmental performance should have been to learn the governance capabilities in more successful countries that ensured the success of specific strategies to deal with critical labour market failures.

We also know that the most successful developers also had strategies for addressing market failures in capital markets that keep savings rates low and prevent investment in many sectors because of inadequate arrangements for risk sharing. Institutional failures, poor contracting and weak state enforcement capacities combine to keep savings rates very low in most developing countries. Even more seriously, the absence of effective institutions to share risk can constrain technology adoption and learning in poor countries[16]. Attempting to construct efficient capital markets through good governance to address these problems is at best a very partial solution because improvements are unlikely to be sufficient or have a significant impact in the short to medium term through this route. This is why the historical evidence shows that countries that were good at catching up had governance capabilities to address these market failures directly to raise savings and investments rates, and to incubate and support learning industries with effective monitoring and exit strategies[16].

There is no question that interventions to correct market failures in many developing countries achieved disappointing results in the past. But if the alternative agenda of achieving significant market efficiency through good governance reforms is an unachievable chimera, then the only realistic option for developing countries is to revisit their own experiences and ask what went wrong. In general, poorly performing developing countries in the $1960 \mathrm{~s}$ had poor growth-enhancing governance capabilities. Compared to their actual capabilities they adopted massively ambitious strategies of intervention that could not be properly managed or enforced. As the capacity to enforce particular strategies depends on specific political conditions, growth-enhancing strategies that worked in one country are not necessarily enforceable in another. This is also why when we look at strategies for correcting market failures and the governance capabilities that allowed this we find significant differences even between successful countries.

The diversity of the experience of successful catching up in Asia tells us that it is important that strategies for correcting market failure have to be backed by effective 
governance capabilities that enable the particular mechanisms through which market failures are being addressed to be effectively implemented. Where political conditions and initial institutional capabilities are strong, governance capabilities for effectively managing significant corrections of market failure are feasible. But in countries where the initial institutional and political conditions are not appropriate for extensive growth-enhancing interventions, the feasible range of interventions will have to be narrower. Moreover, success even in a narrow range of interventions may require developing specific growth-enhancing governance capabilities[3-4].

At the very least, we can assert that the successful East Asian countries did not demonstrate the achievement of good governance defined as market-enhancing governance before their growth takeoffs. Moreover, in no case was there even a commitment to good governance as it is currently defined as a precondition for achieving sustainable development. In the next section we will examine some of the evidence, including the cross section data used by the World Bank and many mainstream economists to argue that good governance reforms are associated with more rapid and sustained development in contemporary developing countries.

\section{The Empirical Evidence}

The market-enhancing view of governance aims to explain the observation of poor performance in many developing countries. Superficially, many poorly performing countries appear to conform to the analysis of the good governance model because they have high levels of corruption, low accountability of political leaders, poor rule of law and plenty of evidence of predatory behaviour. But the superficial evidence can be misleading. All developing countries have poor governance scores as measured by the good governance or market-enhancing characteristics. So if we plot country scores for good governance (these measures are discussed later) against their per capita incomes, we get an almost perfect fit. However, the test that is required is to see if poor countries that scored higher in terms of market-enhancing governance characteristics actually did better in terms of convergence or catching up with advanced countries. When we conduct such a test we find that the evidence supporting the market-enhancing view of governance is very weak indeed. While poorly performing developing countries fail to meet good governance conditions, so do high-growth developing countries. This observation suggests that it is difficult for any developing country, regardless of its growth performance, to achieve the governance conditions required for efficient markets. This does not mean that marketenhancing conditions are irrelevant, but it does mean that we need to qualify some of the arguments made for prioritizing market-enhancing governance reforms in developing countries if the evidence is that these are not possible to achieve.

\section{Evidence: Market-Enhancing Governance and Economic Growth.}

An extensive academic literature has tested the relationship between what we have described as market-enhancing governance conditions and economic performance. This literature typically reports a positive relationship between the two, appearing to support the hypothesis that an improvement in market-enhancing governance conditions will promote growth and accelerate convergence with advanced countries. This literature uses a number of indices of market-enhancing governance. In particular, it uses data provided by Stephen Knack and the IRIS centre at Maryland University, as well as more recent data provided by Kaufmann's team and available 
on the World Bank's website. If market-enhancing governance were relevant for explaining economic growth, we would expect the quality of market-enhancing governance at the beginning of a period (of say ten years) to have an effect on the economic growth achieved during that period.

However, the Knack-IRIS data set is only available for most countries from 1984 and the Kaufmann-World Bank data set only from 1996 onwards. We have to make sure that we test the importance of market-enhancing governance by using the score of a country at the beginning of a period of economic performance to see if initial differences in market-enhancing governance scores can explain the subsequent differences in performance between countries. This is important, as a correlation between governance indicators at the end of a period and economic performance during that period could be picking up the reverse direction of causality, where rising per capita incomes result in an improvement in market-enhancing governance conditions. There are good theoretical reasons to expect market-enhancing governance to improve as per capita incomes increase (as more resources become available in the budget for securing property rights, sustaining democratic systems, fighting corruption and so on). This reverses the direction of causality between growth and governance. Thus, for the Knack-IRIS data, the earliest decade of growth that we can examine would be 1980-90, and even here we have to remember that the governance data that we have is for a year almost halfway through the growth period. The World Bank data on governance begins in 1996, and therefore these can at best be used for examining growth during 1990-2003, keeping in mind once again that these indices are for a year halfway through the period of growth being considered.

Stephen Knack's IRIS team at the University of Maryland compile their indices using country risk assessments based on the responses of relevant constituencies and expert opinion[26]. These provide measures of market-enhancing governance quality for a wide set of countries from the early 1980s onwards. This data provides indices for a number of key variables that measure the performance of states in providing marketenhancing governance. The five relevant indices in this data set are for 'corruption in government', 'rule of law', 'bureaucratic quality', 'repudiation of government contracts', and 'expropriation risk'. These indices provide a measure of the degree to which governance is capable of reducing the relevant transaction costs that are considered necessary for efficient markets. The IRIS data can be used to aggregate these indices into a single 'property rights index' that ranges from 0 (the poorest conditions for market efficiency) to 50 (the best conditions). This index measures a range of market-enhancing governance conditions and is very useful (within the standard limitations of all subjective data sets) for testing the significance of marketenhancing governance conditions for economic development. Annual data for the index are available from 1984 for most countries.

A second data set that has become very important for testing the role of marketenhancing governance comes from Kaufmann's team[27] and is available on the World Bank's website[28]. This data aggregates a large number of indices available in other data sources into six broad governance indicators. These are:

1. Voice and Accountability - measuring political, civil and human rights

2. Political Instability and Violence - measuring the likelihood of violent threats to, or changes in, government, including terrorism 
3. Government Effectiveness - measuring the competence of the bureaucracy and the quality of public service delivery

4. Regulatory Burden - measuring the incidence of 'market-unfriendly' policies

5. Rule of Law - measuring the quality of contract enforcement, the police, and the courts, as well as the likelihood of crime and violence

6. Control of Corruption - measuring the exercise of public power for private gain, including both petty and grand corruption and state capture.

We have divided the countries for which data are available into three groups. "Advanced countries" are high-income countries using the World Bank's classification with the exception of two small oil economies (Kuwait and the UAE), which we classify as developing countries. This is because although they have high levels of per capita income from oil sales, they have achieved lower levels of industrial and agricultural development than other high-income countries. We also divide the group of developing countries into a group of "diverging developing countries" whose per capita GDP growth is lower than the median growth rate of the advanced country group, and a group of "converging developing countries" whose per capita GDP growth rate is higher than the median advanced country rate.

Table 1 summarizes the data for the 1980s from the Knack-IRIS dataset. For the decade of the 1980s, the earliest property right index available in this dataset for most countries is for 1984 .

Table 2 shows the composite data for the 1990s using an aggregation of the indices available in the Kaufmann-World Bank series. Table 3-Table 8 show the KaufmannWorld Bank data for the 1990s for the six indices separately from the KaufmannWorld Bank data set. Figure 2-Figure 9 show the same data in graphical form. The tables and plots demonstrate that the role of market-enhancing governance conditions in explaining differences in growth rates in developing countries is at best very weak.

First, there is virtually no difference between the median property rights index between converging and diverging developing countries. Secondly, the range of variation of the governance index is almost exactly the same for converging and diverging countries. The absence of any clear separation between converging and diverging developing countries in terms of market-enhancing governance conditions should cast doubt on the robustness of the econometric results of a large number of studies that report that improvements in market-enhancing governance conditions have had a significant effect on economic growth[6, 8, 29-30].

Third, for all the indices of governance we have available, the data suggest a very weak positive relationship between the quality of governance and economic growth. The direction of the relationship is as the market-enhancing governance view predicts but the weakness of the relationship demands a closer look at the underlying data. This demonstrates that the positive relationship depends to a great extent on a large number of advanced countries having high scores on market-enhancing governance (the countries shown as diamond-shaped points in Figure 2-Figure 9) and the bulk of developing countries which are diverging or low-growth countries which also have low scores on market-enhancing governance (shown as triangular points). However, if we only look at these countries, we are unable to say anything about the direction of causality as we have good theoretical reasons to expect market-enhancing governance to improve in countries with high per capita incomes. The critical countries for 
establishing the direction of causality are the converging developing countries (shown as square points). These are countries like the East Asian countries and China (but also include some other countries that occasionally enjoy bursts of growth). By and large, converging countries do not have significantly better market-enhancing governance scores than diverging ones. In the 1980s data set, there are relatively very few converging countries, and so the relationship between market-enhancing governance and growth appears to be a positive one using the Knack-IRIS data set. However, in the 1990s data set, the number of converging countries is greater and the positive relationship becomes much weaker both visually and using measures of goodness of fit despite the bias created by the governance indicators only being available from 1996 for the Kaufmann-World Bank data set. The data therefore suggests that even the weak positive relationship between market-enhancing governance and growth could to some extent be based on a reverse causality, with richer countries having better scores in terms of market-enhancing governance.

The policy implications of these observations are rather important. Given the large degree of overlap in the market-enhancing governance scores achieved by converging and diverging developing countries, we need to significantly qualify the claim made in much of the governance literature that an improvement in market-enhancing governance quality in poorly-performing countries is necessary and sufficient to achieve a significant improvement in growth performance. If anything, the data suggests that since differences in market-enhancing governance capabilities are not significant between converging and diverging countries, we need to examine other dimensions of governance capabilities that could explain differences in growth performance.

Table 1 Market-Enhancing Governance: Property Rights and Growth 1980-90

\begin{tabular}{|l|l|l|l|}
\hline & $\begin{array}{l}\text { Advanced } \\
\text { Countries }\end{array}$ & $\begin{array}{l}\text { Diverging } \\
\text { Developing } \\
\text { Countries }\end{array}$ & $\begin{array}{l}\text { Converging } \\
\text { Developing } \\
\text { Countries }\end{array}$ \\
\hline Number of Countries Property Rights & 21 & 52 & 12 \\
\hline $\begin{array}{l}\text { Median } \\
\text { Index 1984 }\end{array}$ & 45.1 & 22.5 & 27.8 \\
\hline $\begin{array}{l}\text { Observed range of Property } \\
\text { Rights Index }\end{array}$ & $25.1-49.6$ & $9.4-39.2$ & $16.4-37.0$ \\
\hline $\begin{array}{l}\text { Median Per Capita GDP } \\
\text { Growth Rate 1980-90 }\end{array}$ & 2.2 & -1.0 & 3.5 \\
\hline
\end{tabular}

The IRIS Property Rights Index can range from a low of 0 for the worst governance conditions to a high of 50 for the best conditions.

Sources: IRIS-3[26], World Bank[31]. 
Table 2 Market-Enhancing Governance: Property Rights and Growth 1990-2003

\begin{tabular}{|l|l|l|l|}
\hline & $\begin{array}{l}\text { Advanced } \\
\text { Countries }\end{array}$ & $\begin{array}{l}\text { Diverging } \\
\text { Developing } \\
\text { Countries }\end{array}$ & $\begin{array}{l}\text { Converging } \\
\text { Developing } \\
\text { Countries }\end{array}$ \\
\hline Number of Countries & 24 & 53 & 35 \\
\hline $\begin{array}{l}\text { Median Property Rights } \\
\text { Index 1996 }\end{array}$ & 47.0 & 25.0 & 23.7 \\
\hline $\begin{array}{l}\text { Observed range of Property } \\
\text { Rights Index }\end{array}$ & $32.3-50.0$ & $10-38.3$ & $9.5-40.0$ \\
\hline $\begin{array}{l}\text { Median Per Capita GDP } \\
\text { Growth Rate 1990-2003 }\end{array}$ & 2.1 & 0.4 & 3.0 \\
\hline
\end{tabular}

The property right index here is an aggregate of the corruption, rule of law, bureaucratic quality indices on a 50 point scale together with the index of repudiation of government contracts and expropriation risk.

Sources: World Bank[28], World Bank[31].

Table 3 Market-Enhancing Governance: Voice/Accountability and Growth 1990-2003

\begin{tabular}{|l|l|l|l|}
\hline & $\begin{array}{l}\text { Advanced } \\
\text { Countries }\end{array}$ & $\begin{array}{l}\text { Diverging } \\
\text { Developing } \\
\text { Countries }\end{array}$ & $\begin{array}{l}\text { Converging } \\
\text { Developing } \\
\text { Countries }\end{array}$ \\
\hline Number of Countries and & 24 & 53 & 35 \\
\hline $\begin{array}{l}\text { Median Voice } \\
\text { Accountability Index 1996 }\end{array}$ & 1.5 & -0.4 & -0.3 \\
\hline $\begin{array}{l}\text { Observed range of Voice and } \\
\text { Accountability Index }\end{array}$ & $0.4-1.8$ & $-1.5-1.1$ & $-1.7-1.4$ \\
\hline $\begin{array}{l}\text { Median Per Capita GDP } \\
\text { Growth Rate 1990-2003 }\end{array}$ & 2.1 & 0.4 & 3.0 \\
\hline
\end{tabular}

The Kaufmann-World Bank index has a normal distribution with mean 0 and standard deviation 1. Sources: World Bank[28], World Bank[31].

Table 4 Market-Enhancing Governance: Political Instability and Growth 1990-2003

\begin{tabular}{|l|l|l|l|}
\hline & $\begin{array}{l}\text { Advanced } \\
\text { Countries }\end{array}$ & $\begin{array}{l}\text { Diverging } \\
\text { Developing } \\
\text { Countries }\end{array}$ & $\begin{array}{l}\text { Converging } \\
\text { Developing } \\
\text { Countries }\end{array}$ \\
\hline Number of Countries & 24 & 53 & 35 \\
\hline $\begin{array}{l}\text { Median Political Instability } \\
\text { and Violence Index 1996 }\end{array}$ & 1.2 & -0.4 & 0.0 \\
\hline $\begin{array}{l}\text { Observed range of Instability } \\
\text { and Violence Index }\end{array}$ & $-0.5-1.6$ & $-2.8-1.1$ & $-2.7-1.0$ \\
\hline $\begin{array}{l}\text { Median Per Capita GDP } \\
\text { Growth Rate 1990-2003 }\end{array}$ & 2.1 & 0.4 & 3.0 \\
\hline
\end{tabular}

The Kaufmann-World Bank index has a normal distribution with mean 0 and standard deviation 1. Sources: World Bank[28], World Bank[31]. 
Table 5 Market-Enhancing Governance: Govt Effectiveness and Growth 1990-2003

\begin{tabular}{|l|l|l|l|}
\hline & $\begin{array}{l}\text { Advanced } \\
\text { Countries }\end{array}$ & $\begin{array}{l}\text { Diverging } \\
\text { Developing } \\
\text { Countries }\end{array}$ & $\begin{array}{l}\text { Converging } \\
\text { Developing } \\
\text { Countries }\end{array}$ \\
\hline Number of Countries & 24 & 53 & 35 \\
\hline $\begin{array}{l}\text { Median Government } \\
\text { Effectiveness Index 1996 }\end{array}$ & 1.9 & -0.5 & -0.2 \\
\hline $\begin{array}{l}\text { Observed range of Govt } \\
\text { Effectiveness Index }\end{array}$ & $0.6-2.5$ & $-2.1-0.8$ & $-2.2-1.8$ \\
\hline $\begin{array}{l}\text { Median Per Capita GDP } \\
\text { Growth Rate 1990-2003 }\end{array}$ & 2.1 & 0.4 & 3.0 \\
\hline
\end{tabular}

The Kaufmann-World Bank index has a normal distribution with mean 0 and standard deviation 1. Sources: World Bank[28], World Bank[31].

Table 6 Market-Enhancing Governance: Regulatory Quality and Growth 1990-2003

\begin{tabular}{|l|l|l|l|}
\hline & $\begin{array}{l}\text { Advanced } \\
\text { Countries }\end{array}$ & $\begin{array}{l}\text { Diverging } \\
\text { Developing } \\
\text { Countries }\end{array}$ & $\begin{array}{l}\text { Converging } \\
\text { Developing } \\
\text { Countries }\end{array}$ \\
\hline Number of Countries & 24 & 53 & 35 \\
\hline $\begin{array}{l}\text { Median Regulatory Quality } \\
\text { Index 1996 }\end{array}$ & 1.5 & -0.1 & 0.2 \\
\hline $\begin{array}{l}\text { Observed range of } \\
\text { Regulatory Quality Index }\end{array}$ & $0.8-2.3$ & $-2.4-1.2$ & $-2.9-2.1$ \\
\hline $\begin{array}{l}\text { Median Per Capita GDP } \\
\text { Growth Rate 1990-2003 }\end{array}$ & 2.1 & 0.4 & 3.0 \\
\hline
\end{tabular}

The Kaufmann-World Bank index has a normal distribution with mean 0 and standard deviation 1. Sources: World Bank[28], World Bank[31].

Table 7 Market-Enhancing Governance: Rule of Law and Growth 1990-2003

\begin{tabular}{|l|l|l|l|}
\hline & $\begin{array}{l}\text { Advanced } \\
\text { Countries }\end{array}$ & $\begin{array}{l}\text { Diverging } \\
\text { Developing } \\
\text { Countries }\end{array}$ & $\begin{array}{l}\text { Converging } \\
\text { Developing } \\
\text { Countries }\end{array}$ \\
\hline Number of Countries & 24 & 53 & 35 \\
\hline $\begin{array}{l}\text { Median Rule of Law Index } \\
1996\end{array}$ & 1.9 & -0.4 & -0.3 \\
\hline $\begin{array}{l}\text { Observed range of Rule of } \\
\text { Law Index }\end{array}$ & $0.8-2.2$ & $-1.8-1.1$ & $-2.2-1.7$ \\
\hline $\begin{array}{l}\text { Median Per Capita GDP } \\
\text { Growth Rate 1990-2003 }\end{array}$ & 2.1 & 0.4 & 3.0 \\
\hline
\end{tabular}

The Kaufmann-World Bank index has a normal distribution with mean 0 and standard deviation 1. Sources: World Bank[28], World Bank[31]. 
Table 8 Market-Enhancing Governance: Corruption and Growth 1990-2003

\begin{tabular}{|l|l|l|l|}
\hline & $\begin{array}{l}\text { Advanced } \\
\text { Countries }\end{array}$ & $\begin{array}{l}\text { Diverging } \\
\text { Developing } \\
\text { Countries }\end{array}$ & $\begin{array}{l}\text { Converging } \\
\text { Developing } \\
\text { Countries }\end{array}$ \\
\hline Number of Countries & 24 & 53 & 35 \\
\hline $\begin{array}{l}\text { Median Control of } \\
\text { Corruption Index 1996 }\end{array}$ & 1.8 & -0.4 & -0.3 \\
\hline $\begin{array}{l}\text { Observed range of Control of } \\
\text { Corruption Index }\end{array}$ & $0.4-2.2$ & $-2.0-0.8$ & $-1.7-1.5$ \\
\hline $\begin{array}{l}\text { Median Per Capita GDP } \\
\text { Growth Rate 1990-2003 }\end{array}$ & 2.1 & 0.4 & 3.0 \\
\hline
\end{tabular}

The Kaufmann-World Bank index has a normal distribution with mean 0 and standard deviation 1. Sources: World Bank[28], World Bank[31].

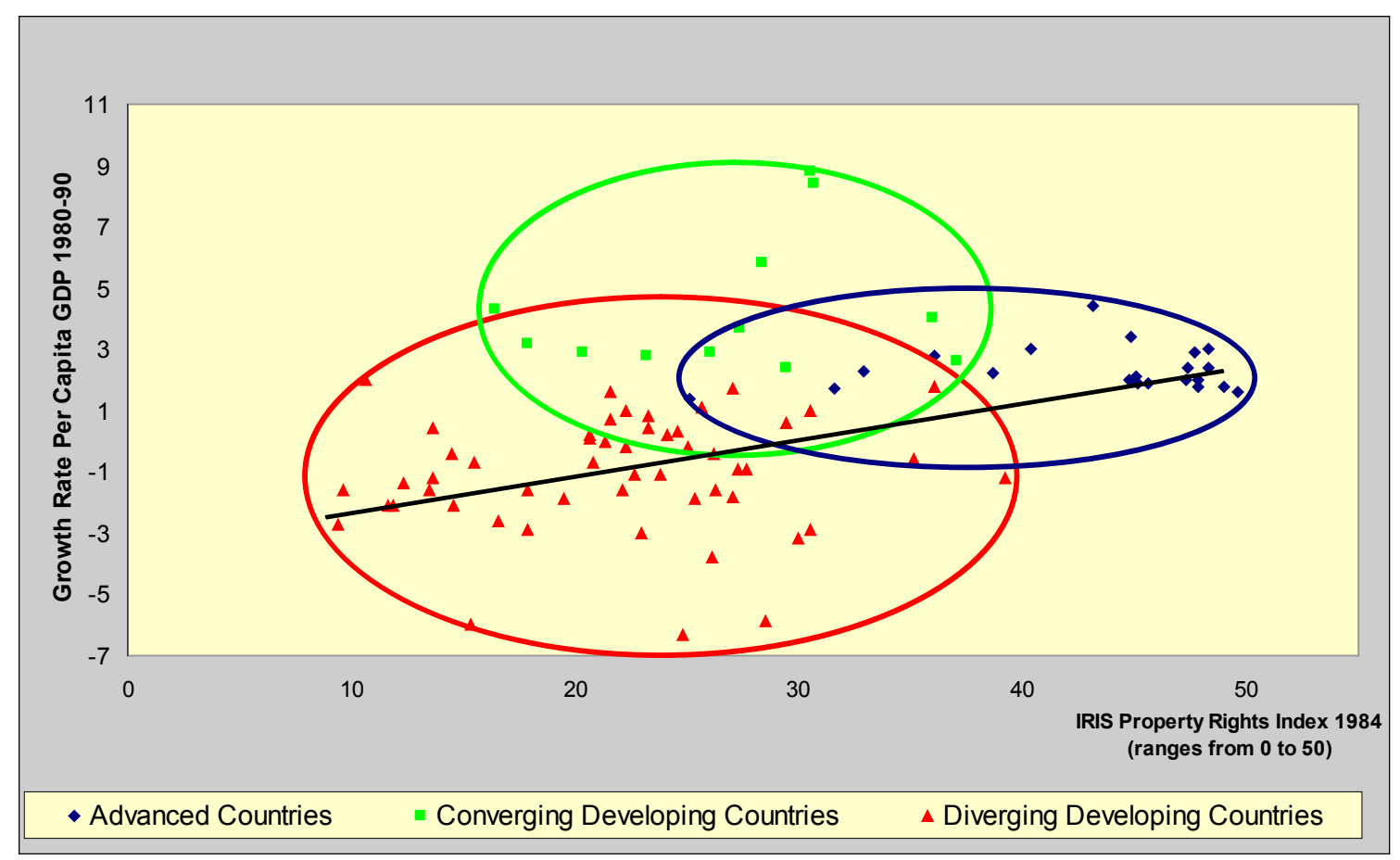

Figure 2 Market-Enhancing Governance and Growth 1980-90 


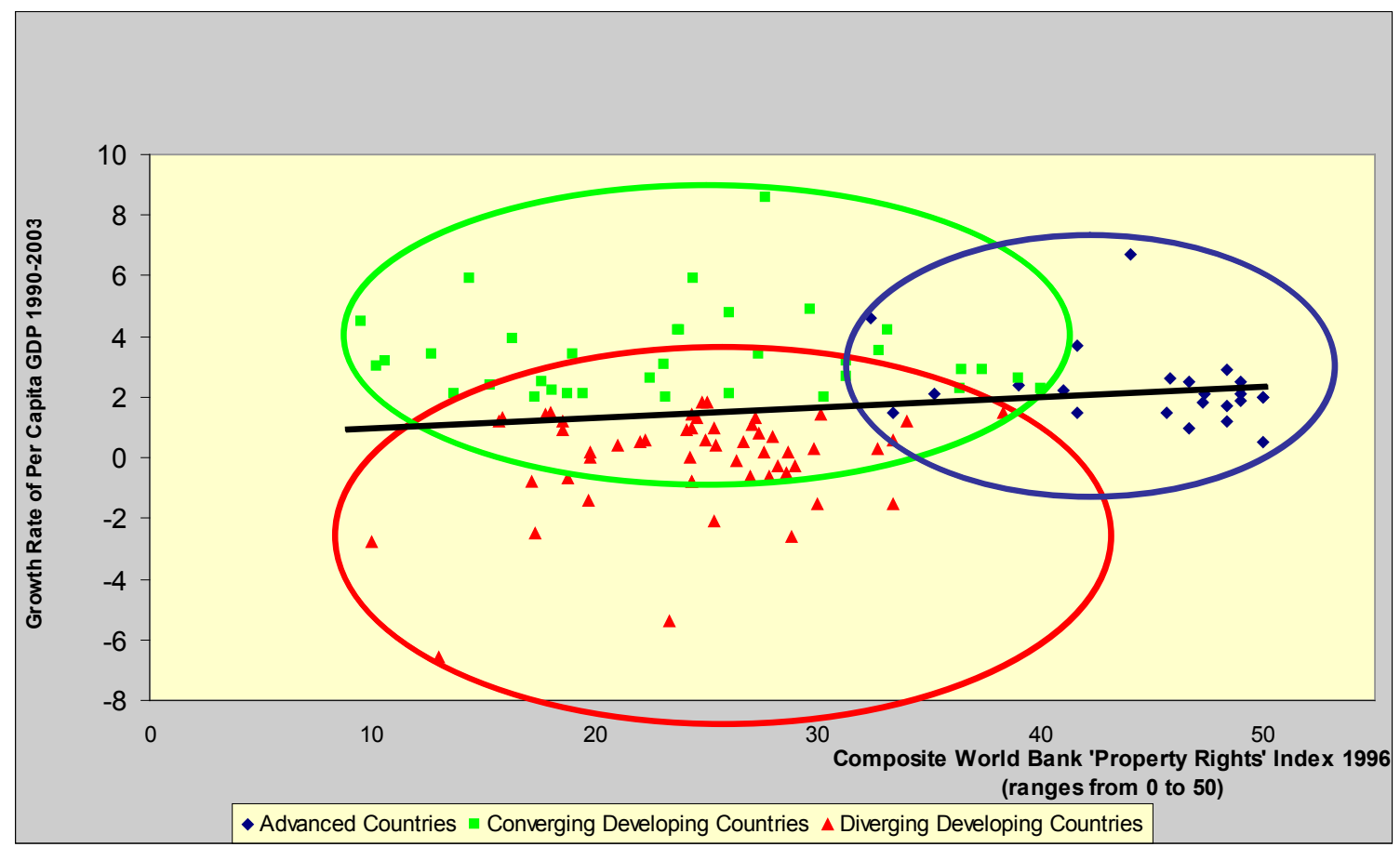

Figure 3 Market-Enhancing Governance and Growth 1990-2003

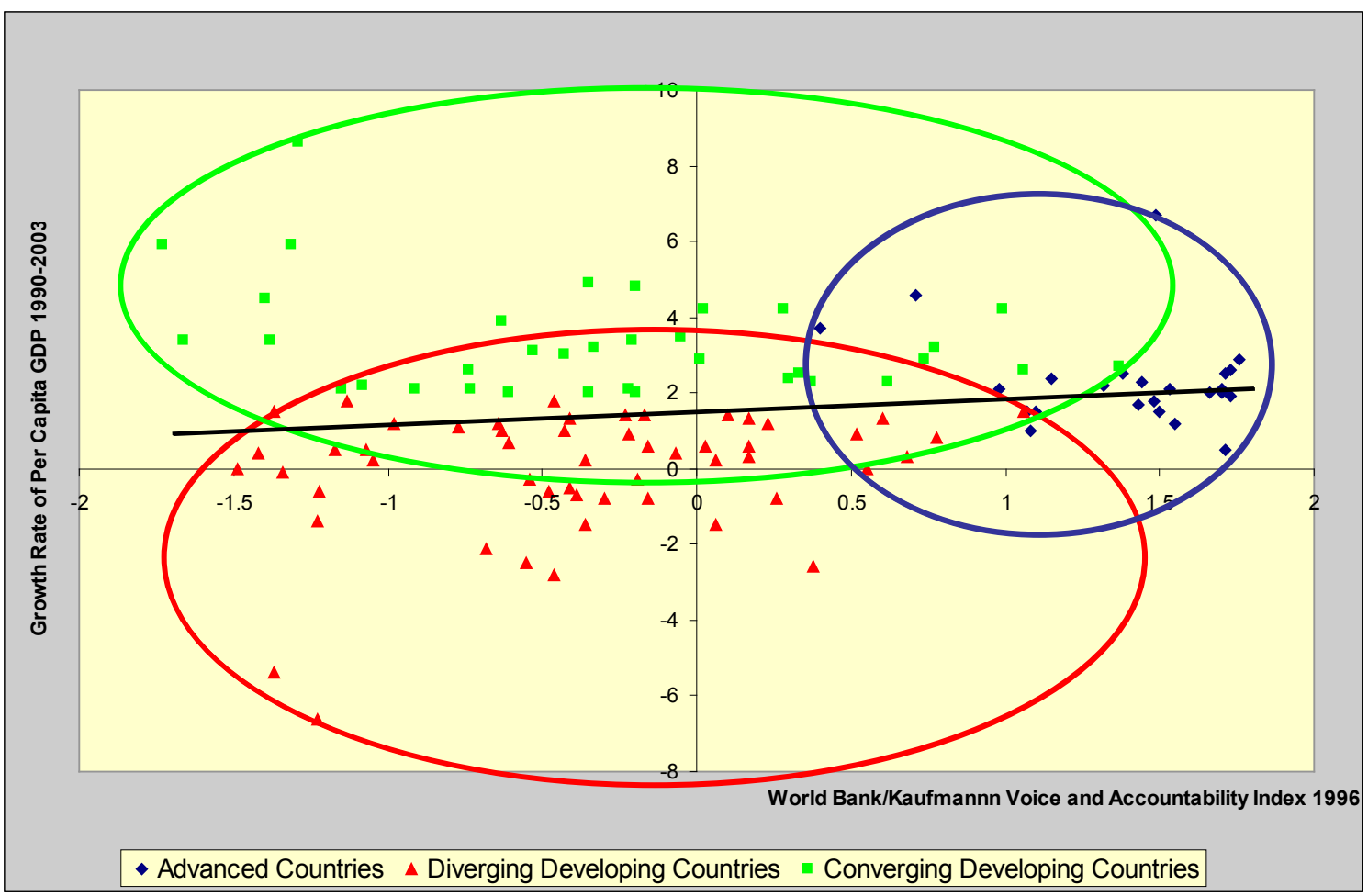

Figure 4 Political Accountability and Growth 1990-2003 


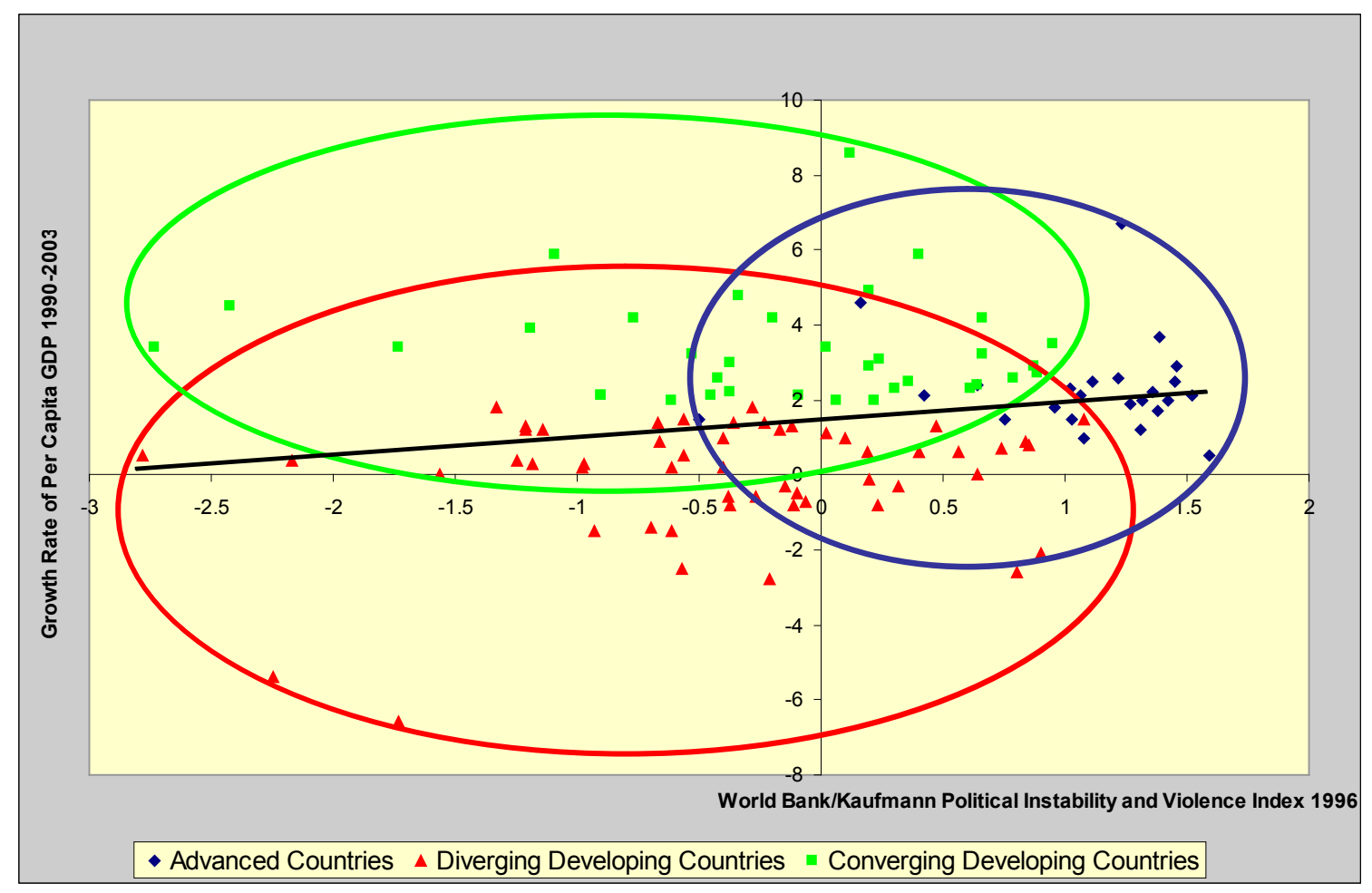

Figure 5 Political Instability and Growth 1990-2003

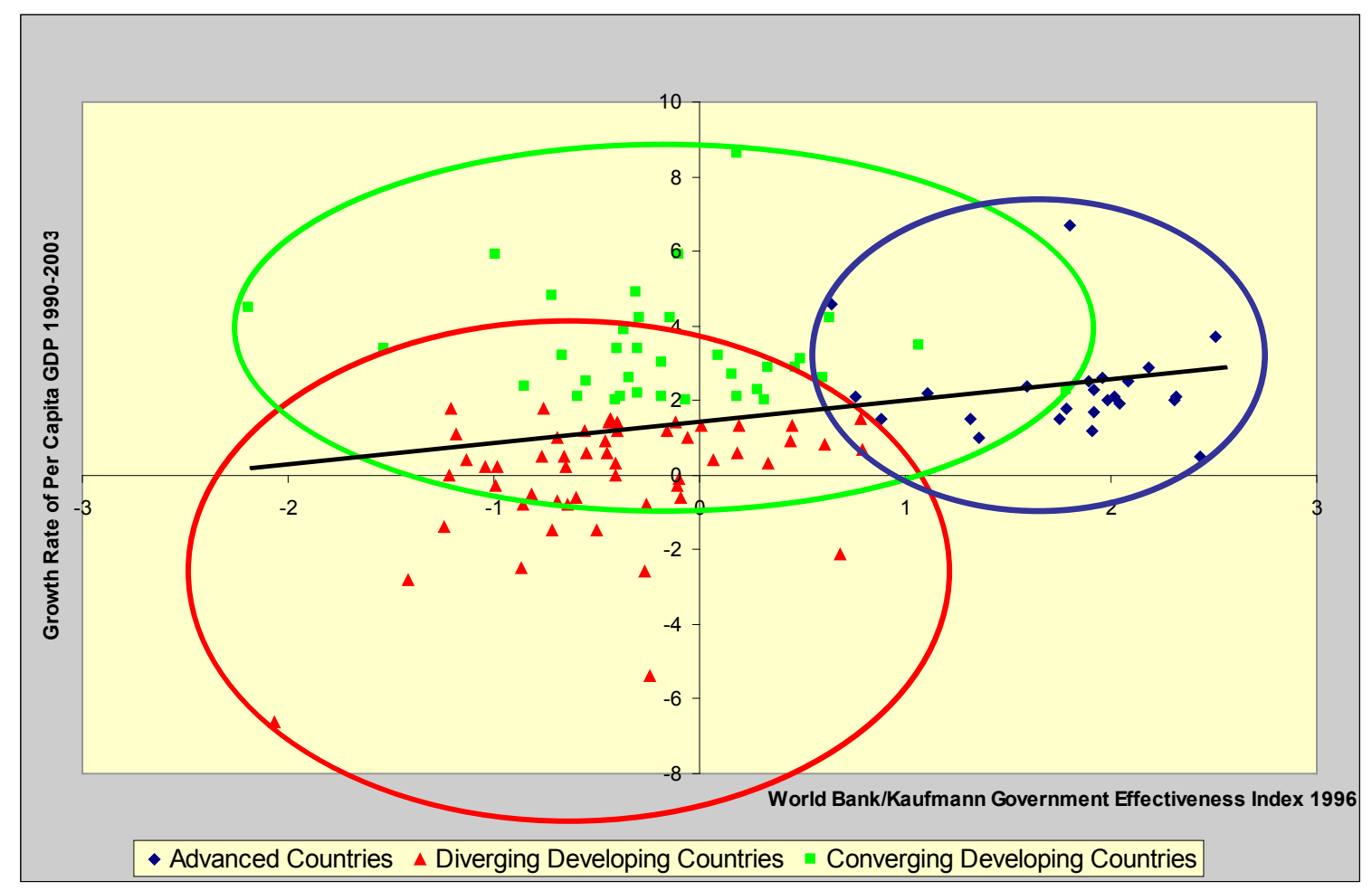

Figure 6 Government Effectiveness and Growth 1990-2003 


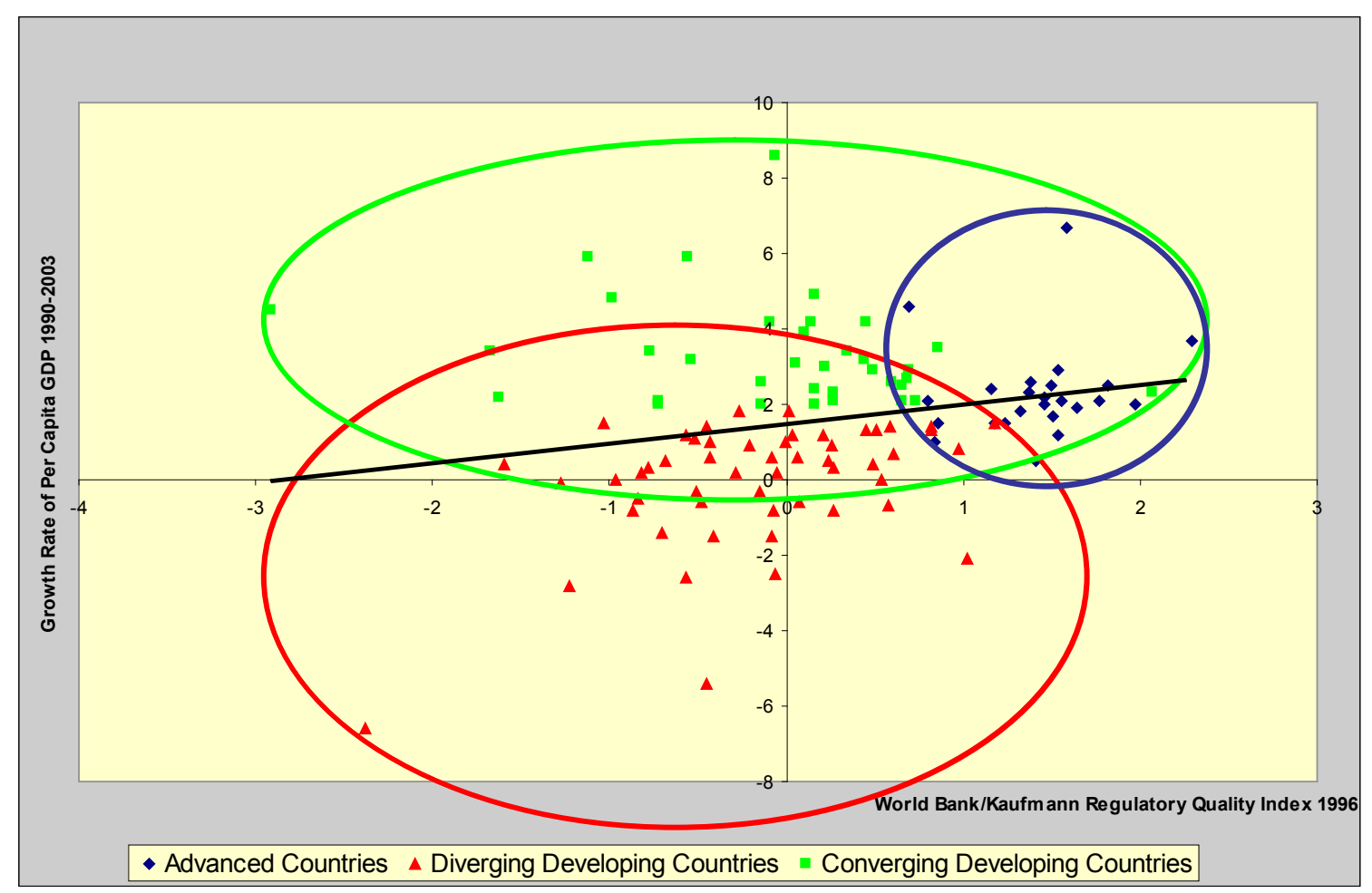

Figure 7 Regulatory Quality and Growth 1990-2003

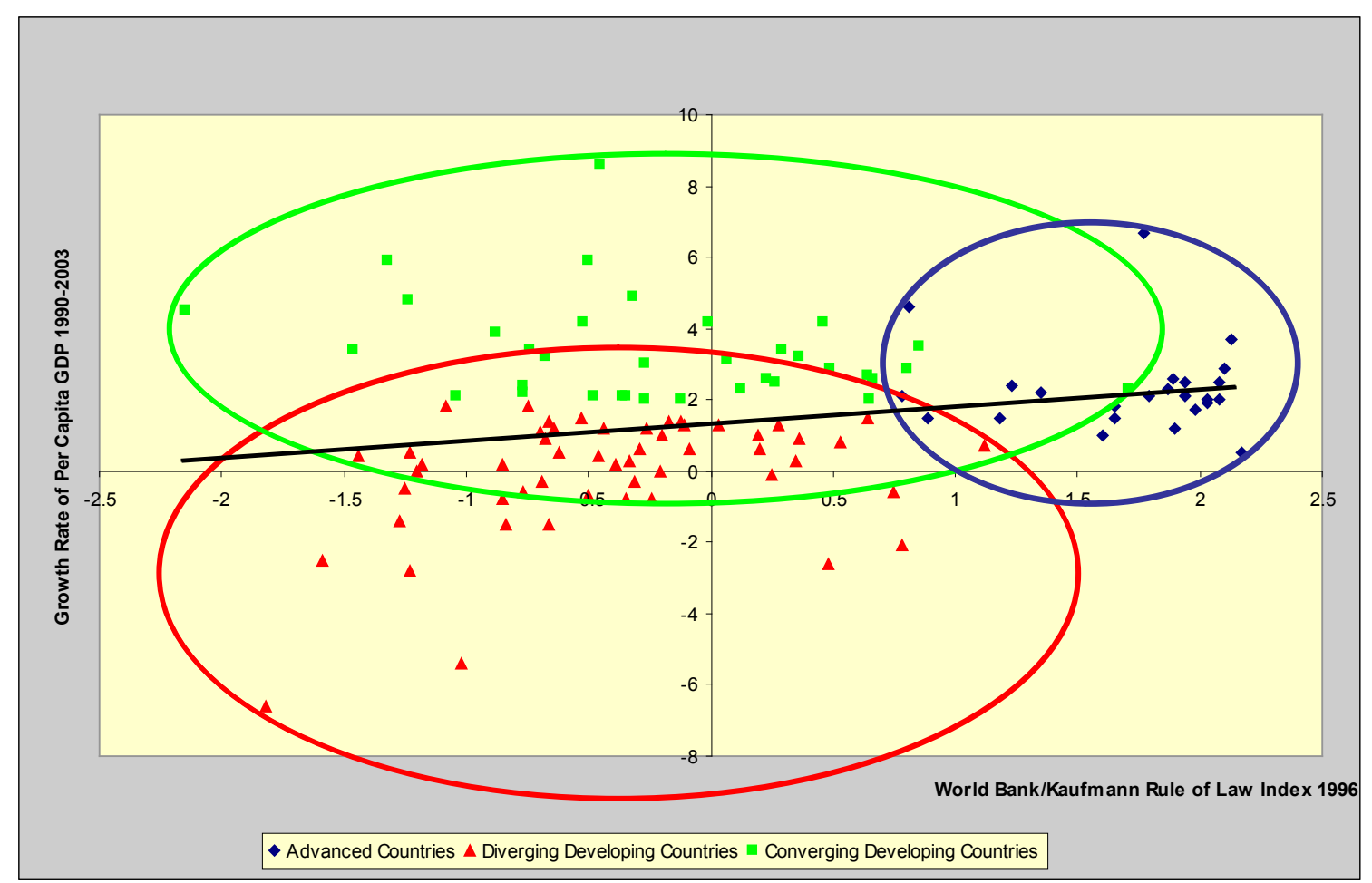

Figure 8 Rule of Law and Growth 1990-2003 


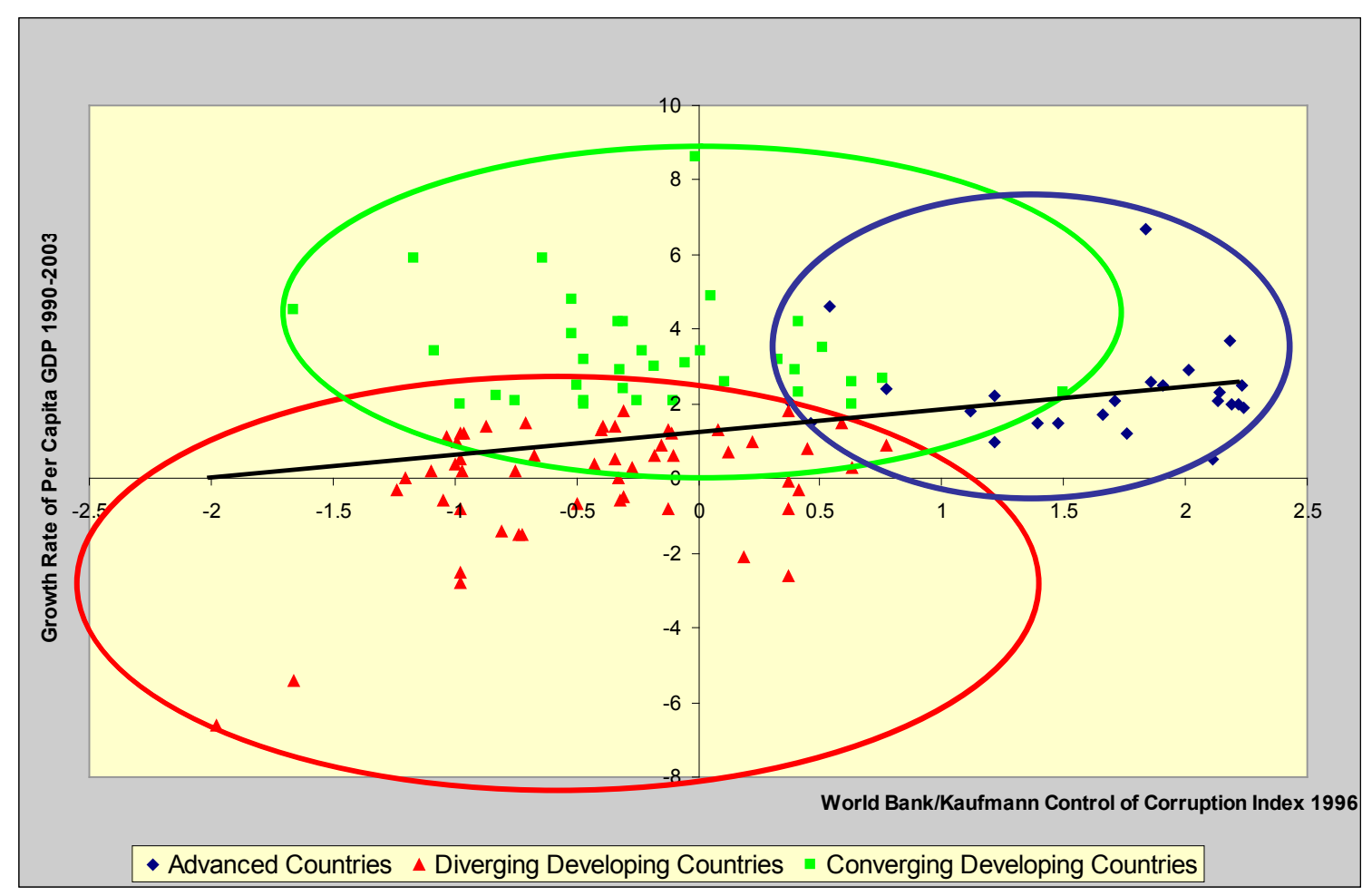

Figure 9 Control of Corruption and Growth 1990-2003

The many studies that find a significant positive relationship between marketenhancing governance and growth usually do so by pooling advanced and developing countries together, or pooling together developing countries at different levels of development. Our examination of the data suggests that these studies can be misleading because we expect more advanced countries to have better market governance capabilities. Advanced countries are also expected to have lower growth rates in general because they are already close to the technology frontier. It is therefore difficult to separate these effects statistically given the complex relationships between per capita incomes, governance capabilities and growth rates in pooled data. When developing countries are looked at separately the relationship between market-enhancing governance indicators and growth rates is much weaker if it exists at all, and even in this case, we need to be aware of sample selection problems if we pool relatively advanced and poorer developing countries.

The causality problem here has to be carefully defined. We do not have to reject the hypothesis that if market-enhancing governance could be improved perhaps growth would be higher. It is quite plausible that an improvement in market-enhancing governance capabilities would have a positive effect on growth. The problem rather is the observation that in fact market-enhancing governance appears not to be easy to improve in poor countries. In that case, market-enhancing governance is once again not causally responsible for growth even though in theory an improvement in these conditions may have helped.

These observations suggest that to identify the critical governance capabilities for sustaining growth and development it is important to look at individual countries that have made a successful transition from underdevelopment to sustained development. This brings us to the Asian high-growth countries of the late twentieth century. Case 
studies of the governance conditions of these countries demonstrate very strongly that none of them conformed to the expectations of good governance theory[32-33].

Our argument is also supported by the analysis of growth in African countries by Sachs and his collaborators[34]. In their study of African countries these authors point out that economies with higher per capita incomes are expected to have better marketenhancing governance quality. As a result, higher scores on governance indicators should not be used to explain higher incomes. To correct for this bias, they argue that market-enhancing (good governance) indicators should not be directly used as explanatory variables. Instead they use the deviation of the country's governance indicator (in this case the Kaufmann-World Bank index) from the predicted value of the indicator given that country's per capita income at the beginning of the period. This approach is a sophisticated way of dealing with the two-way causation between governance and growth. If market-enhancing governance matters for growth, we would expect countries that had better governance than expected for their per capita incomes to do better in subsequent periods compared to countries that only achieved average or below average governance for their per capita incomes. The Sachs study finds that when adjusted in this way, market-enhancing governance has no effect on the growth performance of African countries. This result is entirely consistent with our observations.

However, we do not entirely agree with the Sachs study when they conclude that these results show that governance reforms are not an immediate priority for African countries. They argue that to trigger growth in Africa what is required instead is a big push in the form of a massive injection of investment in infrastructure and disease control. While the case for a big push in Africa is strong, this does not mean that African countries have the minimum necessary governance conditions to ensure that a viable economic and social transformation will be unleashed by such an investment push. The evidence of big push experiments in many countries has demonstrated that growth is only sustainable if resources are used to enhance productive capacity and new producers are able to achieve productivity growth and competitiveness. These outcomes are not likely in the presence of significant market failures and therefore require support from state structures possessing the appropriate governance capabilities to overcome these market failures.

The econometric results reported by Sachs et al.[34] do not actually show that all types of governance were irrelevant for growth, only that the market-enhancing governance measured by available governance indicators did not explain differences in performance between these developing countries. Other forms of governance may be very important, but indices measuring these governance capacities are not readily available. In our next section we look at the evidence suggesting the importance of growth-enhancing governance capabilities.

On the other hand, our interpretation of the evidence appears to be contradicted by the influential paper by Acemoglu et al.[35] They argue that the achievement of stable property rights decades or even longer ago enabled some countries to become prosperous while others who failed to achieve these conditions stagnated. Their argument uses instrumental variables to measure the stability of property rights a century or more ago. Their now-famous indicator is the relative frequency of deaths of white settlers in different parts of Africa that determined whether or not Europeans 
set up settler colonies with stable property rights. Where malaria deaths were low, white settlers went and settled and set up states which protected property rights. In contrast, white settlers stayed away from places where malaria deaths were high and instead set up extractive colonies where property rights were destabilized by colonial powers. They then find a strong correlation between low malaria deaths a long time ago (proxying for stable property rights being set up) and current per capita incomes, suggesting that stable property rights were significant in explaining prosperity.

This analysis is seductive in its use of innovative statistical techniques but suffers from serious historical problems. Most significantly, the underlying historical processes that the instrumental variables are capturing do not actually support the interpretation of the authors. The countries where settlers went and settled in did not enjoy stable property rights while the settlers were taking over these societies. Indeed, they suffered from precipitous collapses of traditional property rights as large tracts of land were expropriated by colonial settlers. In some cases the expropriation was so severe and rapid that indigenous populations collapsed entirely, sometimes in genocidal proportions. To describe the growth that happened as being due to the prior establishment of stable property rights does violence to the historical facts.

It is more accurate to say that where the transformation of property rights to capitalist ones happened very rapidly through the use of exceptional amounts of violence, capitalist economies emerged earlier. In these countries, which are the ones where white settlers went to, the transition to productive economies allowed the establishment of good governance. The rapid emergence of viable capitalist economies subsequently allowed property rights to be protected and become stable in the way we would expect. In other developing countries the process of transformation is still going on. In one sense, we could even argue that property rights were more stable in the non-settler countries because a precipitous historical rupture did not occur there. The problem for these countries is that similar property right transitions have to be organized today in a context where markets remain inefficient and subject to high transaction costs.

The reform challenge is to organize transitions in these countries with less violence and more justice than the processes through which the apparently good governance countries with white settler histories emerged. Of course once a viable capitalism becomes established, property rights are likely to become well protected because the new owners of rights will be willing to spend resources to protect their rights. In settler colonies this happened quite a long time ago, but the stability of property rights across the board in these societies did not predate the establishment of a productive capitalism. In other words, Acemoglu et al.'s argument suffers from exactly the type of causality problem as the other good governance arguments we discussed earlier, despite their use of more sophisticated econometrics and proxy variables.

Our empirical interpretation is strongly supported by recent work being done at the French development agency, the AFD, by Nicolas Meisel and Jacques Aoudia[36], whose work replicates our findings using a new data set. They borrow our classification of developing countries into converging and diverging groups and find exactly the same pattern that we have described. The replication of our findings using an independent data set suggests that our argument is robust. 
The task of further research is to distinguish between different types of developing countries within the converging and diverging groups. We know that these groups include countries of quite different prospects and of course levels of development. For instance, converging countries include some countries that are growing rapidly because of mineral resources, countries that are growing because they possess a comparative advantage in some low-technology manufacturing exports, and yet others that are on sustainable growth paths with strong technology acquisition strategies and productivity growth. Clearly, the last subset is the most interesting one and is the subset that others within the converging set should attempt to emulate if they are to sustain their growth rates. Similarly, within the diverging group there are various types of countries, including some middle-income countries that have run into serious problems of sustaining productivity growth as well as some very poor countries that have not yet achieved a takeoff. Further research into these different subsets will enhance our understanding of the governance challenges that different types of countries face in attempting to either trigger or sustain growth and development. In each case, the answer may be to develop specific governance capabilities to enhance growth that are quite different from the general good governance reforms suggested by the market-enhancing governance approach.

\section{Evidence: Growth-Enhancing Governance and Economic Growth}

The case for growth-enhancing governance argues that markets in developing countries are bound to be relatively inefficient because of high transaction costs. As a result developing countries are likely to face significant market failures in transferring assets and resources to growth sectors, in attracting the best and most appropriate technologies requiring prolonged periods of learning, and in providing the right mix of training and incentives for skills enhancement. In consequence, growth through the expansion of new productive capacity and systematically moving up the value chain is likely to be heavily constrained in most developing countries. Not surprisingly, successful developing countries demonstrate a variety of institutions and governance capabilities to address these major areas of market failure, together with institutional and political capacities to achieve sufficient inclusion to manage political stability during transitions that are bound to involve periods of conflict, strife and tension[3233].

The case study evidence strongly supports our analysis. Asset and land market failures are significant in developing countries and prevent growth sectors getting access to all their resources purely through market processes. Historically, processes of non-market asset transfers have been very diverse, as have been the required governance capabilities to ensure their efficiency. Examples include the English Enclosures from the $16^{\text {th }}$ to the $18^{\text {th }}$ century, which transferred common lands in rural England to emerging capitalist sheep farmers through parliamentary acts and led to the agrarian revolution that was the basis of the subsequent industrial revolution in England. The creation of the chaebol in South Korea in the 1960s using transfers of public resources to the chaebol is another example of effective growth-enhancing governance capabilities on the part of the South Korean state to make valuable resources available to potentially productive new industrial activities and firms. The creation of the Chinese TVEs using public resources in the 1980s and their gradual transfer to private hands in the 1990s is another example of an effective growthenhancing strategy backed by appropriate governance capabilities. 
As for failures in labour and capital markets that slow down technological upgrading and the upskilling of labour, the empirical evidence particularly from East Asia and China also strongly support the importance of growth-enhancing governance capabilities for implementing targeted corrections to these market failures. In successful countries, incentives for technology acquisition were created using many different mechanisms including tariff protection (in virtually every case but to varying extents), direct subsidies to large firms investing in new technologies (in particular in South Korea), subsidized and prioritized infrastructure for priority sectors (in China and Malaysia), subsidizing the licensing of advanced foreign technologies (in Taiwan), and managing the foreign exchange value of the currency (in many early developers and recently in China). The governance capabilities of countries to manage these incentives played a critical part in determining the relative success of countries in moving up the value chain. In successful countries incentives were changed over time in line with changing technological and market conditions. Firms and sectors that did not perform could not expect to receive incentives forever. In less successful performers, these governance capabilities did not exist and strategies of moving up the value chain failed in the end[21,37].

Thus, one area in which poor countries need to focus on is on national investment and technology policies as a means of achieving technological upgrading[38]. The success of these strategies will in turn depend on the development of governance capabilities in these countries to manage the identification and provision of incentives for investment in technological upgrading. These are difficult governance capabilities, but not necessarily more difficult than trying to achieve across the board rule of law reforms or anti-corruption reforms in poor countries, and they have at least the support of historical evidence from East Asia as achievable governance goals for poor countries. Clearly, most poor countries will not be immediately able to emulate China or South Korea in the scale of their ability to encourage new investments. But it is nevertheless very important for developing countries to understand these success stories and why successes in these countries were not necessarily achieved by following a good governance or market-enhancing strategy.

Developing countries then need to develop their own institutional experiments appropriate to their political and institutional initial conditions to address the most significant market failures that are constraining growth in their core economic sectors. The main lesson they should learn from China and East Asia is that appropriate governance capabilities to implement these policies are critical. But clearly, most countries should begin with modest local experiments to upgrade existing sectors and technologies in countries that currently have weak governance capabilities, aiming to gradually build up growth-enhancing governance capabilities.

The importance of these governance capabilities are also indicated by the histories of poorly performing countries because we know that when governments intervene to correct market failure without the governance capabilities to manage and enforce these strategies, the outcome can be disappointing. If the requisite governance capacities are missing, a growth-enhancing strategy may have high costs of government failure, as poorly implemented interventions may fail to improve resource allocation significantly while suffering from high rent-seeking costs. 
Paradoxically, the very diversity of strategies for correcting market failures in successful countries can be cause for optimism because it means that a variety of growth-enhancing governance capabilities can play a role in a country's development effort. While a full understanding of this diversity can only be achieved by studying a series of case studies, Table 9 summarizes these experiences for a selection of countries showing the type of growth-enhancing strategies that they followed and the associated governance capabilities that either supported or obstructed the implementation of these strategies. During the 1960s and into the 1980s, most developing countries followed variants of growth-enhancing strategies that had common elements even though they often differed significantly in their detail. In all countries, the two primary goals of developmental interventions were a) to accelerate resource allocation to growth sectors and b) to accelerate technology and skills acquisition in these sectors.

To achieve the first, a variety of policy mechanisms were used including bureaucratic allocation of land (including land reform), the licensing of land use, influencing the allocation and use of foreign exchange and influencing the allocation of bank credit. In some cases, price controls and fiscal transfers were also used to accelerate the transfer of resources to particular sectors. To achieve the second, incentives for technology acquisition included targeted tax breaks or subsidies, protection of particular sectors for domestic producers engaged in setting up infant industries, licensing of foreign technologies and subcontracting these to domestic producers, setting up investment zones for high technology industries and subsidizing infrastructure for them, and subsidizing higher education and skills acquisition of different types. The critical observation from the perspective of governance strategies is that for both types of policies, success required the possession or development of very specific governance capabilities to effectively implement the strategies being followed. These included in particular, the capability to monitor resource use and withdraw resources or support from activities that proved to be making inadequate progress.

The growth-enhancing governance challenge for countries is to first identify the most important market failures constraining growth in that country, to identify possible responses to these market failures and finally picking responses which can either be implemented given existing governance capabilities or which may become viable if critical governance capabilities can be developed. In most countries, sufficient growth-enhancing governance capabilities do not exist to implement very significant responses to critical market failures. At the same time, an attempt to suddenly achieve a high level of growth-enhancing governance capabilities is also likely to fail. A pragmatic appraisal of what is feasible should guide the development of a growthenhancing governance reform agenda for each country[38]. 
Table 9 Growth-Enhancing Governance in Selected Countries 1960-2000

\begin{tabular}{|c|c|c|c|}
\hline & $\begin{array}{c}\text { Critical Components of Growth- } \\
\text { Enhancing Strategy }\end{array}$ & $\begin{array}{l}\text { Supportive or Obstructive } \\
\text { Governance Capabilities }\end{array}$ & $\begin{array}{l}\text { Economic } \\
\text { Outcomes }\end{array}$ \\
\hline $\begin{array}{l}\text { South Korea } \\
\text { 1960s to early } \\
1980 \text { s }\end{array}$ & $\begin{array}{l}\text { Non-market asset allocations } \\
\text { (consolidations, mergers and } \\
\text { restructuring of chaebol). } \\
\text { Targeted conditional subsidies for } \\
\text { chaebol to accelerate catching-up. }\end{array}$ & $\begin{array}{l}\text { Centralized and effective governance } \\
\text { of interventions by agencies with } \\
\text { long-term stake in development. } \\
\text { Effective power to implement } \\
\text { assisted by weakness of political } \\
\text { factions so that inefficient subsidy } \\
\text { recipients are unable to buy } \\
\text { protection from them. }\end{array}$ & $\begin{array}{l}\text { Very rapid growth } \\
\text { and capitalist } \\
\text { transformation }\end{array}$ \\
\hline $\begin{array}{l}\text { Malaysia } \\
\text { 1980s 1990s }\end{array}$ & $\begin{array}{l}\text { Public sector technology } \\
\text { acquisition strategies using public } \\
\text { enterprises with subcontracting for } \\
\text { domestic firms. } \\
\text { Targeted infrastructure and } \\
\text { incentives for MNCs with } \\
\text { conditions on technology transfer. }\end{array}$ & $\begin{array}{l}\text { Moderately effective centralized } \\
\text { governance of interventions. } \\
\text { Assisted by centralized transfers to } \\
\text { intermediate classes which reduced } \\
\text { incentives of political factions to seek } \\
\text { rents by protecting inefficient firms. }\end{array}$ & $\begin{array}{l}\text { Rapid growth and } \\
\text { capitalist } \\
\text { transformation }\end{array}$ \\
\hline $\begin{array}{c}\text { Indian } \\
\text { subcontinent } \\
\text { 1960s 1970s } \\
\text { (With some } \\
\text { variations these } \\
\text { characteristics } \\
\text { describe many } \\
\text { developing } \\
\text { countries of that } \\
\text { period) }\end{array}$ & $\begin{array}{l}\text { Targeted subsidies to accelerate } \\
\text { catching up in critical sectors } \\
\text { (using protection, licensing of } \\
\text { foreign exchange, price controls } \\
\text { and other mechanisms). } \\
\text { Public sector technology } \\
\text { acquisition in subsidized public } \\
\text { enterprises. } \\
\text { Resource transfers to growth } \\
\text { sectors using licensing and pricing } \\
\text { policy. }\end{array}$ & $\begin{array}{l}\text { Moderate to weak governance } \\
\text { capacities to discipline non- } \\
\text { performing rent recipients. Agencies } \\
\text { often have contradictory goals } \\
\text { defined by different constituencies. } \\
\text { Fragmented political factions help to } \\
\text { protect the rents of the inefficient for } \\
\text { a share of these rents. } \\
\text { State capacities decline as committed } \\
\text { and intelligent individuals leave. }\end{array}$ & $\begin{array}{l}\text { Public and private } \\
\text { sector infant } \\
\text { industries often fail } \\
\text { to grow up. } \\
\text { Rent seeking costs } \\
\text { are often the most } \\
\text { visible effects of } \\
\text { intervention. } \\
\text { Moderate to low } \\
\text { growth and slow } \\
\text { transformation }\end{array}$ \\
\hline $\begin{array}{l}\text { Indian } \\
\text { subcontinent } \\
\text { 1980s 1990s }\end{array}$ & $\begin{array}{l}\text { Liberalization primarily in the form } \\
\text { of a withdrawal of implicit targeted } \\
\text { subsidies, in particular through the } \\
\text { relaxation of licensing for capital } \\
\text { goods imports. } \\
\text { Much more gradual withdrawal of } \\
\text { protection across the board for } \\
\text { domestic markets. }\end{array}$ & $\begin{array}{l}\text { Moderate to weak governance } \\
\text { capacities to implement remain but } \\
\text { do less damage as the scope of } \\
\text { growth enhancing policies decline. } \\
\text { Fragmented political factions } \\
\text { continue to have an effect on market- } \\
\text { enhancing governance by restricting } \\
\text { tax revenues and making it difficult } \\
\text { to construct adequate infrastructure. }\end{array}$ & $\begin{array}{l}\text { Growth led by } \\
\text { investments in } \\
\text { sectors that already } \\
\text { have comparative } \\
\text { advantage. } \\
\text { Higher growth but } \\
\text { limited to a few } \\
\text { sectors. }\end{array}$ \\
\hline $\begin{array}{l}\text { Latin America } \\
1950 \text { s to } 1970 \mathrm{~s}\end{array}$ & $\begin{array}{l}\text { Domestic capacity building } \\
\text { through selective tariffs and } \\
\text { selective credit allocation. }\end{array}$ & $\begin{array}{l}\text { Governance effective in directing } \\
\text { resources to import-substituting } \\
\text { industries but weak in disciplining } \\
\text { poor performers. } \\
\text { Weakness linked to "corporatist" } \\
\text { alliances that constrained } \\
\text { disciplining powerful sectors. }\end{array}$ & $\begin{array}{l}\text { Initial rapid growth } \\
\text { slows down. } \\
\text { Many infant } \\
\text { industries fail to } \\
\text { grow up. }\end{array}$ \\
\hline $\begin{array}{l}\text { Latin America } \\
\text { 1980s onwards }\end{array}$ & $\begin{array}{l}\text { Rapid liberalization across the } \\
\text { board. }\end{array}$ & $\begin{array}{l}\text { Focus on market-enhancing } \\
\text { governance. } \\
\text { Breakdown of corporatist alliances } \\
\text { allows rapid liberalization to be } \\
\text { implemented. }\end{array}$ & $\begin{array}{l}\text { Output growth in } \\
\text { sectors that already } \\
\text { have comparative } \\
\text { advantage, in } \\
\text { particular in } \\
\text { commodities. }\end{array}$ \\
\hline
\end{tabular}

\section{Conclusions}

The desirability of many of the objectives of the good governance agenda is not in question. Many social groups and constituencies in developing countries want to see a 
deepening of democracy, greater accountability of their governments, a clampdown on corruption and the introduction of a rule of law and stable property rights. Many of these goals should indeed be long-term goals of development in their own right. The policy question for developing countries is rather about the extent to which these goals are immediately achievable and the extent to which they should be prioritized as targets given that reform capabilities are limited and the resources to effectively implement reforms even more so. Here, the theoretical arguments and historical evidence suggest that we should be very careful not to confuse means with ends, goals with preconditions, methods with outcomes. There is no credible evidence of any poor country that has first achieved significant improvements in its democratic accountability, reduced corruption to very low levels in a sustainable way, achieved a recognizably good rule of law and stable property rights and as a result achieved significantly high and sustainable growth and development. There are good reasons why such empirical examples cannot be found.

All of the available evidence is that the achievement of conventional good governance has been through a simultaneous and parallel set of improvements in good governance in line with the achievement of economic prosperity. This is because significant resources and productive political constituencies are required to achieve the effective implementation of good governance goals, and these resources and constituencies are themselves the outcome of growth and development. There is no question that the achievement of these conditions can further improve confidence in contracts and markets, and thereby further improve market efficiency, allowing growing economies to enjoy virtuous cycles of improvements in governance and economic performance. However, the precondition for these virtuous cycles to emerge is that there is a sustainable prior strategy of promoting growth and development and states have capabilities to sustain these strategies.

Unfortunately, largely for ideological reasons, the promotion of state capabilities to sustain growth through addressing critical market failures in poor countries has fallen out of the reform agenda, particularly in the international discourse promoted by rich countries, the international financial institutions and the donor community. Yet, the actual evidence of growth and development from the most successful developers of the twentieth century, and in particular from China today, suggests that these growthenhancing governance capabilities are the most important ones, if growth is to be sustained and that these are in turn the real preconditions for the interactive development of market-enhancing governance capabilities over time.

Fortunately, there is a growing perception in the policy community that the focus on good governance has been a diversion from the most pressing tasks of governance capability improvements. Consequently there are some encouraging signs of a readjustment of the reform agenda. These shifts need to be welcomed and a new agenda of reform has to be developed rapidly as frustration with conventional reform strategies grows in many poorly performing and fragile societies. Nevertheless, we should expect strong resistance from many existing reformers, economists and advisors whose reputations have been based on the old agenda, and who feel threatened by any radical shift in policy. However, the indications on the ground are that these reformers have failed to achieve sustainable improvements in terms of their own reforms, defined as sustainable reductions in corruption, improvements in the rule of law or in perceptible improvements in the accountability of their governments. 
This is often despite the expenditure of vast amounts of grants and loans in the pursuit of the good governance agenda. Some of these economies are growing, but any examination of the drivers of growth in these countries shows that their economies are often growing due to niche sectors that are struggling to perform despite what the government is doing rather than benefiting from significant improvements in market efficiency as a result of reforms carried out under the good governance agenda.

The danger of an exclusive focus on market-enhancing governance is that we may lose opportunities for carrying out critical reforms that are more likely to produce results. We may also create disillusionment with governance reforms leading to the emergence of a false perception that governance does not matter that much for economic development. The urgency of shifting the focus of reforms to growthenhancing governance is underlined by the fact that these reforms require a very different set of discussions with stakeholders to identify critical market failures. This in turn needs to be followed by the careful identification of the most appropriate ways of addressing these critical market failures in the specific context of that country and depending on the potential of developing appropriate governance capabilities.

All of these processes will take time and involve a very different set of procedures than the ones that have raised awareness of good governance deficits. Given the stark situation in terms of policy space and limited reform capabilities, the only option for most developing countries is to embark on the growth-enhancing governance agenda on a relatively small scale. I have elsewhere described this as a 'Hirschmanian' approach to pursuing growth-enhancing governance reforms[38-39]. Developing countries can expect little help or assistance from western donors and financial institutions in this area given the dominant ideologies informing the understanding of these players. It is not surprising that the successful developers of East Asia did not develop any of their most important governance capabilities to address market failures as a result of advice or persuasion coming from advanced countries.

It is important to reassert the importance of governance reforms at a time when the failure of much of the good governance agenda in delivering strong results is resulting in reform fatigue and the perception that perhaps governance is not after all very important for poor countries. This would be an unfortunate conclusion given the historical evidence that the absence of (growth-enhancing) governance capabilities has severely constrained poor countries from solving market failures that have constrained their growth and development. Rather, the conclusion should be that while the good governance (or market-enhancing governance) goals are in many cases desirable long-term goals for all countries, many of these goals are not achievable to any significant degree in poor countries. They are certainly not achievable to an extent that market efficiency will improve so much that other governance reform goals become irrelevant. On the contrary, the governance capabilities that need to be prioritized in developing countries are likely to be variants of the growth-enhancing governance capabilities required for dealing with critical market failures that we find in successful and sustained growth experiences in East Asia, China and elsewhere. 


\section{References}

1. Krueger, A.O., Government Failures in Development. Journal of Economic Perspectives, 1990. 4(3): p. 9-23.

2. Krueger, A.O., The Political Economy of the Rent-Seeking Society. American Economic Review, 1974. 64(3): p. 291-303.

3. Khan, M.H., Governance, Economic Growth and Development since the 1960s, in Growth Divergences: Explaining Differences in Economic Performance, J.A. Ocampo, K.S. Jomo, and R. Vos, Editors. 2007, Orient Longman, Zed Books and Third World Network: Hyderabad, London and Penang. p. 285-323.

4. Khan, M.H., Governance and Development: The Perspective of GrowthEnhancing Governance, in Diversity and Complementarity in Development Aid: East Asian Lessons for African Growth, GRIPS Development Forum, Editor. 2008, National Graduate Institute for Policy Studies: Tokyo. p. 107-52.

5. North, D.C., Institutions, Institutional Change and Economic Performance. 1990, Cambridge: Cambridge University Press.

6. Kauffman, D., A. Kraay, and P. Zoido-Lobatón, Governance Matters, in World Bank Policy Working Paper. 1999, World Bank: Washington.

7. Acemoglu, D., S. Johnson, and J.A. Robinson, Institutions as the Fundamental Cause of Long-Run Growth, in Working Paper. 2004, National Bureau of Economic Research: Cambridge Mass.

8. Knack, S. and P. Keefer, Why Don't Poor Countries Catch Up? A CrossNational Test of an Institutional Explanation. Economic Inquiry, 1997. 35(3): p. 590-602.

9. Mauro, P., Corruption and Growth. Quarterly Journal of Economics, 1995. 110(3): p. 681-712.

10. Mauro, P., The Effects of Corruption on Growth, Investment and Government Expenditure, in Working Paper WP/96/98 Policy Development and Review Department. 1996, International Monetary Fund: Washington.

11. Mauro, P., The Effects of Corruption on Growth, Investment and Government Expenditure: A Cross-Country Analysis, in Corruption and the Global Economy, K.A. Elliot, Editor. 1997, Institute for International Economics: Washington. p. 83-107.

12. Mauro, P., Why Worry about Corruption? IMF Economic Issues, 1997. 97/6: p. 1-12.

13. Olson, M., The Rise and Decline of Nations. 1982, London: Yale University Press.

14. Olson, M., The New Institutional Economics: The Collective Choice Approach to Economic Development in Institutions and Economic Development, C. Clague, Editor. 1997, Johns Hopkins University Press: Baltimore. p. 37-64.

15. Olson, M., Dictatorship, Democracy and Development, in A Not-so-Dismal Science: A Broader View of Economies and Societies, M. Olson and S. Kähkönen, Editors. 2000, Oxford University Press: Oxford. p. 119-37.

16. Khan, M.H., Rents, Efficiency and Growth, in Rents, Rent-Seeking and Economic Development: Theory and Evidence in Asia, M.H. Khan and K.S. Jomo, Editors. 2000, Cambridge University Press: Cambridge. p. 21-69.

17. Stiglitz, J.E., Whither Socialism? 1996, Cambridge Massachusetts: MIT Press.

18. Khan, M.H., The New Political Economy of Corruption, in Development Policy in the Twenty-First Century: Beyond the Post Washington Consensus, 
B. Fine, C. Lapavitsas, and J. Pincus, Editors. 2001, Routledge: London. p. 112-135.

19. Khan, M.H., Corruption and Governance in Early Capitalism: World Bank Strategies and their Limitations, in Reinventing the World Bank, J. Pincus and J. Winters, Editors. 2002, Cornell University Press: Ithaca. p. 164-184.

20. Khan, M.H., Determinants of Corruption in Developing Countries: the Limits of Conventional Economic Analysis, in International Handbook on the Economics of Corruption, S. Rose-Ackerman, Editor. 2006, Edward Elgar: Cheltenham. p. 216-244.

21. Khan, M.H., Rent-seeking as Process, in Rents, Rent-Seeking and Economic Development: Theory and Evidence in Asia, M.H. Khan and K.S. Jomo, Editors. 2000, Cambridge University Press: Cambridge. p. 70-144.

22. Khan, M.H., Markets, States and Democracy: Patron-Client Networks and the Case for Democracy in Developing Countries. Democratization, 2005. 12(5): p. 705-25.

23. Khan, M.H., State Failure in Developing Countries and Strategies of Institutional Reform, in Annual World Bank Conference on Development Economics Europe (2003): Toward Pro-Poor Policies: Aid Institutions and Globalization, B. Tungodden, N. Stern, and I. Kolstad, Editors. 2004, Oxford University Press and World Bank: Oxford. p. 165-195.

24. Toye, J., Dilemmas of Development: Reflections on the Counter-Revolution in Development Theory and Policy. 1987, Oxford: Basil Blackwell.

25. Stiglitz, J.E., Making Globalization Work. 2007, London: Penguin.

26. IRIS-3, File of International Country Risk Guide (ICRG) Data, Stephen Knack and the IRIS Center, Editor. 2000, University of Maryland: College Park.

27. Kaufmann, D., A. Kraay, and M. Mastruzzi, Governance Matters IV: Governance Indicators for 1996-2004, in World Bank Policy Research Working Paper. 2005.

28. World Bank, Governance Indicators: 1996-2004. 2005, Washington DC: World Bank.

29. Hall, R. and C. Jones, Why Do Some Countries Produce So Much More Output Per Worker Than Others? Quarterly Journal of Economics, 1999. 114(1): p. 83-116.

30. Knack, S. and P. Keefer, Institutions and Economic Performance: CrossCountry Tests Using Alternative Institutional Measures. Economics and Politics, 1995. 7(3): p. 207-227.

31. World Bank, World Development Indicators 2005 CD-ROM. 2005, Washington DC: World Bank.

32. Aoki, M., H.-K. Kim, and M. Okuno-Fujiwara, eds. The Role of Government in East Asian Economic Development: Comparative Institutional Analysis. 1997, Clarendon Press: Oxford.

33. Khan, M.H. and K.S. Jomo, eds. Rents, Rent-Seeking and Economic Development: Theory and Evidence in Asia. 2000, Cambridge University Press: Cambridge.

34. Sachs, J.D., et al., Ending Africa's Poverty Trap. Brookings Papers on Economic Activity, 2004. 2004(1): p. 117-240.

35. Acemoglu, D., S. Johnson, and J.A. Robinson, The Colonial Origins of Comparative Development: An Empirical Investigation. American Economic Review, 2001. 91(5): p. 1369-1401. 
36. Meisel, N. and J.O. Aoudia, Is "Good Governance" a Good Development Strategy?, in Working Paper. 2008, Agence Française de Développement (AFD): Paris.

37. Amsden, A., Asia's Next Giant: South Korea and Late Industrialization. 1989, Oxford: Oxford University Press.

38. Khan, M.H., Investment and Technology, in National Development Strategies Policy Guidance Notes. 2006, United Nations Development Programme and United Nations Department of Economic and Social Affairs: New York.

39. Khan, M.H., Building Growth-Promoting Governance Capabilities, in Background Paper for The Least Developed Countries Report 2008. 2008, UNCTAD: Geneva. 